\title{
Correction to: Analog circuit architecture for max and min pooling methods on image
}

\author{
Melih Yildirim ${ }^{1}$ (D)
}

Published online: 10 December 2021

(C) Springer Science+Business Media, LLC, part of Springer Nature 2021

\section{Correction to: Analog Integrated Circuits and Signal Processing (2021) 108:119-124 https://doi.org/10.1007/s10470-021-01842-x}

The original version of this article unfortunately contained a mistake. The author's given name has been set as initial in the article as 'M. Yildirim' but the author name should have been 'Melih Yildirim'.
The original article has been corrected.

Publisher's Note Springer Nature remains neutral with regard to jurisdictional claims in published maps and institutional affiliations.

The original article can be found online at https:// doi.org/10.1007/s10470-021-01842-x.

\footnotetext{
Melih Yildirim

melih.yildirim@tubitak.gov.tr

1 The Scientific and Technological Research Council of Turkey (TUBITAK), Ankara, Turkey
} 